\title{
WILMA AIM, Grand Prize Winner
}

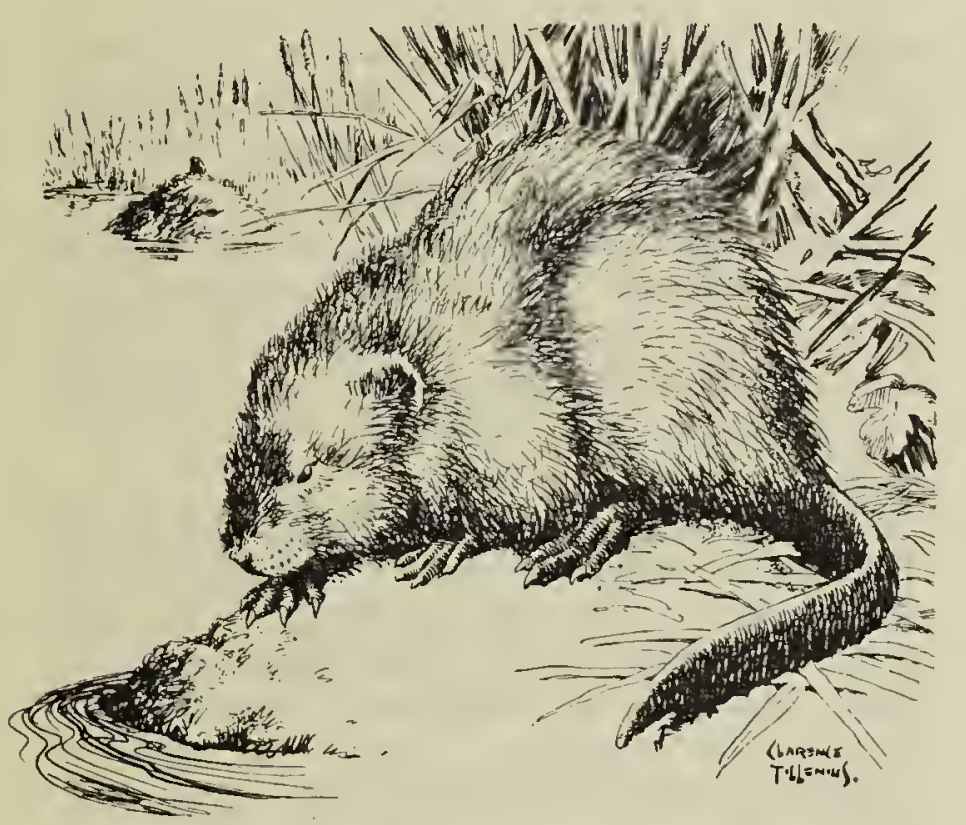

Johnny, "The Muskrat-one of the

Other winners to date, with prize follows:

\section{January, February, March 1954}

Henry Savard, Carvel, Alta.

Field Guide to the Birds

Dr. C. J. Houston, Yorkton

Bob Buhr, Mennon, Sask.

Field Guide to the Birds Dr. Sigga Houston, Yorkton

George M. Hruska, Gerald, Sask. Wild Flower Guide

Dr. Stuart Houston, Yorkton

\section{April, May, June 1954}

D'Arcy Wershler, Yorkton, Sask.

Field Guide to the Birds

L. T. Carmichael, Regina

\section{July, August, September 1954}

Wilma Aim, Bredenbury, Sask.

Field Guide to the Birds

Cliff Shaw, Yorkton

Elizabeth Hubbard, Grenfell, Sask.

Wild Flower Guide

Margaret Belcher, Regina

Anne Matthews, Nipawin, Sask.

Field Guide to the Butterflies Mrs. Stuart Houston, Yorkton

\section{October, November, December 1954}

Anne Matthews, Nipawin, Sask. Field Guide to the Birds

Mrs. John Hubbard, Jr., Grenfell

Wilma Aim, Bredenbury, Sask.

Wild Flower Guide

Dr. Jim Perdicaris, Yorkton

Heather McLaughlin, Indian Head

Wild Flower Guide Dr. G. F. Ledingham, Regina
The winner of the grand prize of the BLUE JAY Jubilee school nature essay contest (from entries in the past seven issues of the BLUE JAY) has been announced by the final judges, J. Frank Roy and Dr. R. M. Bremner, both of Saskatoon.

The winner is Miss Wilma Aim, age 13, Grade 9, Bredenbury High School, for her article "Furry Boarders" in the July-August-Sept. 1954 issue of the BLUE JAY. The grand prize is a $\$ 50$ Balda camera donated by Bird Films Ltd., Regina. The camera was presented to the Society by Tom Ellis of Bird Films.

At the Annual Meeting it was voted to continue this contest, giving one Field Guide as first prize for the best essay printed in each issue, and one year's subscription to the BLUE JAY for any other essays printed.

selected, and name of donor are as

January, February, March 1955

Laverne Wendell, McNutt, Sask. Field Guide to the Birds Dr. R. Bremner, Saskatoon

Evelyn Mess, Saltcoats, Sask.

Field Guide to the Birds Tony Capusten, Prince Albert

Bill Greschuk, Two Hills, Alta. Field Guide to the Mammals E. W. Brooman, Prince Albert

April, May, June 1955

Bob Buhr, Mennon, Sask.

Field Guide to the Mammals Ralph Stueck, Abernethy

Colleen Farrell, Tonkin, Sask.

Field Guide to the Birds E. Symons, Rocanville

Lynne Maddaford, Saltcoats, Sask. Wild Flower Guide Doug Gilroy, Regina

\section{Juiy, August, September 1955}

Valerie Johnson, Sturgis, Sask. Field Guide to the Birds J. Frank Roy, Saskatoon

Anne Matthews, Nipawin, Sask. Field Guide to the Mammals Jack Shaver, Regina 